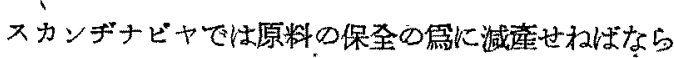
ずアメリカでは補給が迫付かず，例充ば Inter Na-

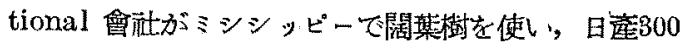
トンと傳えられて招り亦するAmerican Viscose が

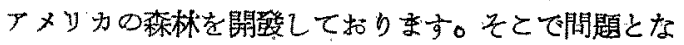
るのなとれる國と出來ない國の開題であります。出來 ない國では輪入せねね゙はらず，その第パルブ工場と密

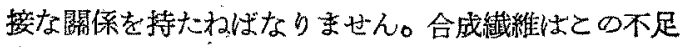
解決の一方法と乙て大きな意義があるのであります。 石若，石灰石，電氣等の原料は土地に遮したものをと り, 飧源を背景として新しい登達を起し, 新しい文化
を創るのですります。日本の間題になるべき所は，我 タが解決しなければならないので崖りまして，フメリ カやヨーロッパが新しい繊維界を作つたに龂して日本 ではどんな繊維界を作るかというととですります。私

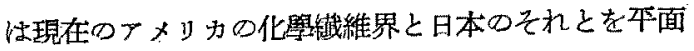



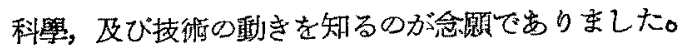
緎維工業界に於ける一つの見透乙をせめてものてとと いたしましてお話を終ります。(本稿は去る10月17日

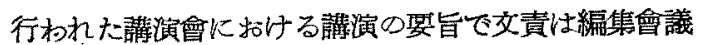
《あり)

\title{
米國攻化と纎 維工業（講演要旨）
}

富士紀績株式會社

私は只今御紹介比預りました堀であります。私の先 般の旅行侍特心繊維工業の䫓察のためではなく，更要

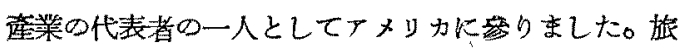
行は先左の指示比上り行わ水ましたのて，專門分野の 呼究は少なく，主として經營，勞資，統制，厚生方面 の視察研究でありまして，之により我が日本の连業を より近代化し，民主化するととがその目的ですりまて た。特に罍學會より依赖がありましたのでことに發表 ナるととに致しました。

\section{一般産業について}

私の抢涪するととは一般莲業の狀態及び瀻維工業に 於ても，極く常識的な經營的な面加ら觀察したもので,

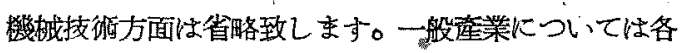
個人によつて多少意見を異にすると思い京すが，私の


あると思います。

(1) 高儥銀であるてと。

アメリカの生活水淮は非常に高く，それに隹して勞

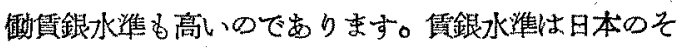
れの8倍乃至10倍の所出ります。生活水淮もややそ の㟟にあると思います。

(2) 大显生座方式であるとと。

國內而場が庶大で購置力が非常に安定しているので,
堀文本

所謂マスプロ方式を殆ど總べての座業に探用している のでありすす。

(3) 機械化自動化がざれているとと。

種々の條件により高度の機械化が可能であります。 又現に行初れて居ります。先に迅べした二つの事柄 に關聯しまして，要らゆる高度の機栈を利用して人手 を減らして居ます。

(4) 科學的經管であるとと。

單に技術面のみならず，基礎研究が非常に進して居 ます。佮不斷の研究をむらる分野仿於て行つている ととが特街でありましょら。フメリカの發展愁榮の基 碟子此處にあると云い得るでしよう。一方我國ではと の科學的經啙を輕峴しているが，アメリカでは澡くと の研究に重點真いています。フメリカの會社に於て;

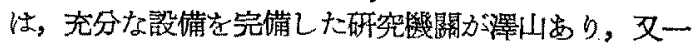
般厹共用としても非常に完储した研究機閣を有して居 ります。私はピッシバーグにするメロンの研究所を見 學致しました。の研究所には各專門の從業員が数十

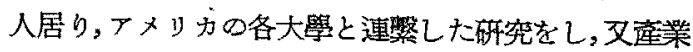
會社の專門技石者と共同研究をすることすむります。 研究者恃早急の研究結果を望まず，一意研究に沒頭致 して居ります。との楾なととは日本に於ては，望まれ ぬ軎でありまして，資本の蓄棈がないのもとの一因て あります。今後に沾ける國際競争を考えるならば，我 
國に充分なる研究機閣の充演が急務であると考兄ます。 我々は之により充分なる研究をせねばならないのであ ります。

\section{販責方法について}

貶賣の方法については色々の事柄があるが，次の項 目に分けることが出來ます。先ず第一に商品が洕費者 の喜んで求めるものでなければなりなせん。消費者の

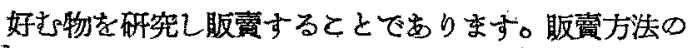
研究でありますが，例えばアメ正力に於ては月賦販賞 的のすのか非常に利用されています。ラシオ，テレ゙ イション; 自動事等は觜とれであります田舍地方と の取引性しい型錄を利用して、メールオーダーによ り販路を求めて居ります。文高價なものに對しては貸 賃を取つて貸付けています。所謂貸付機械の方法がと られていすす。璂盘に立つて種々研究が行的れて 居ります。

\section{勞資の關係について}

日本の勞資關係之較べると，非常に異つています。 今日のアメリカの勞資關係は良く出來て居り旨く行つ

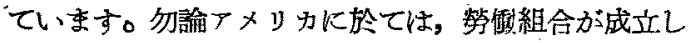
てから可成りの年月を䋔ているので，息く洗練されて

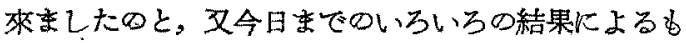
のでありますが，勞資が括互に相手の立場を良く理解

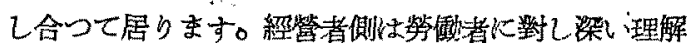

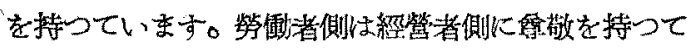
居り，日本の柡な階級閏争恃考えられない。假りにあ


て，社會的な穻賞な結論で和解が成立していはす。人

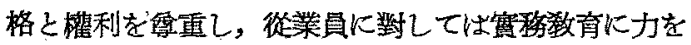
入れています。例えば會社で映畫を見せたり，仕事を

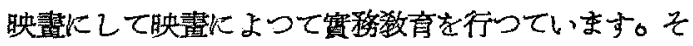
れが能率向上に役立つてい京す。スナメリカでは勞働 組合が發達しているにも拘らず，大きな會社でも組合 を作つていないるのか相賞にありすす。フメリカの等

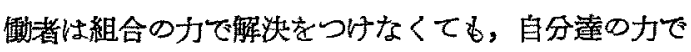

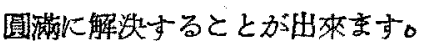

\section{勞働法規について}

日本の勞働法規とは大いに異つていはす。鐵道，電

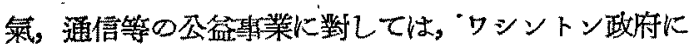
於て洗規を決定して居りますが，一般業や私企業に




して8時間であるが，所によつて10時聞の所もる， 及12時間の所も安りますし，全然無制限の所もるる狀 態であります。少年や女子の取扳いも州によつて買つ

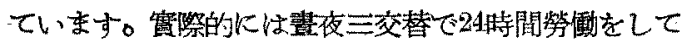
いる所も声ります。例之ば日本儿於ては女子の梁夜作

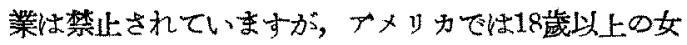
子の深夜作業は州の淄可を得れば可能ですります。最 低售銀制度るワシントン政府が一つのモデルを示すの みであつて，全州に行构れて居ない。日本の場合には

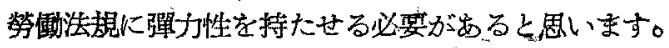

\section{常識的に見た維維工業の現狀について}

私の見ました所ではアメリカに於ても，そんなに篮 つていない樣偲和れました。一方直工業に於ては大 きなギャッブがありました。例充ば鐡工業に於ては石 炭の良質のものが，日本の牛值で得られるし，及鏡䥄

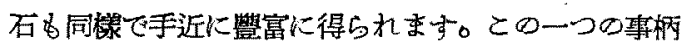
を見ましていッンデキャップのするととが分ります。 かくの如く原料面ばかりでなく，一方に於て機沩設諎 を充分に用意しているといらととでありすす。私の見 學しました機械工場们於ても多量生産のために，高價 な機械を設備して居り又設備が可能なので家ります。 緻密な精密幾械工場と自動事工昜を見學しましたが，


とは困嚾で方ります。所謂流れ作業が行われて居りま した。化學工業は見學することは出來ませんでしたが， 特殊のものを除いては开ら打ちするととは出來ないと 思いました。が一人繊維工業のみは豫期に反して，日


大體日本の紡績 10 塥と大美なく、スフ，人絹に於て も專門化して來てい主す。本では一到が数種の製品 を作つてい衣すが，アメリカではえが專門化して一社 一品製造という傾向になつて來ています。之によりま 乙て生產は單純化乙能率が良く生座が上り機械化が可 能となります。フメリカに於ては原料が手近に豐富に あり，自分に適するものが自由に入手可能であります 乙，㕛市場か德大して來て居り安定しているのて，そ の樣な傾向になつて來ていると思的れます。我國に括 きさしては外國传存の原料のために單純化は不可能さ

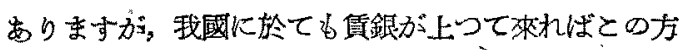
问に向わねばなりません。 
フメリカに於ては緀維の基礎研究の發達る非常なる Фて，瀻維烧對する分析的，科學的研究が盛儿K行わ れて居ります。湿紡，湜織の方浩及び破究に於ては日 本より數段の進步を示して居ります。䋐維の相互砋究 に重點を置き纎維綜合研究所が出來ています。䋐維の 生產設借に於ては大體同じですが，部分的には自動化 されています。日本で嶈來との方法を换用する必要 があります。技術の向上め及ならず，スピードナップ を行い，自動化により人手を省くととに努力していは す。仕上工程でも格段の進步が見られをした。この方 面に於ても更に更に研究の必要が崖ります。

\section{䌦維原料について}

棉花の方は需要閣係はそろ大きな䋠化はなく，人絹， スフ，合成瀻維に棉花が押され氣昧の樣子であります が，全體の割合ではとらでするが，絕對消費量は減つ ていないのであります。人絹スフの方面では，ビスコ 一ス人絹が主としてタイヤコード用に使的れていて被 服用には用いず，被服用としてばア七テート人絹が專 ら使和れています。スフは可成りの登達をして，スフ の2の分野有するに至りま七たが，更に發展の餘 地がすると思います。人絹としては單に人絹一本の， のは，飽和壯態にある感がありますが，他の瀻維との 湿紡，湜織の分野か開拓されると見ている。日本の生 糸の代りにナイロンが使わ狆て居りますが，鞉下を除

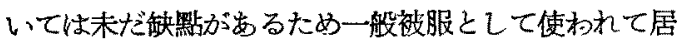
りま账ん。現在てはれれを補らためにオーロンが登場 して來ました。私は充分瀻維製品を見るととが出來な

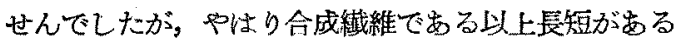
ため，今後は天然瀻維たる生系とオ一ロンの交織があ ると考壳られて來ます。 この際つけ加える事ま合成瀻維工業に於て，ビ二-
ル系の棓脂工業の發澾して來た事であります。戰時中 は專ら策需用として，㕛現在ては在需用として警くべ き淮步をとげたプラスデクの事でありすす。何處の 家庭の隅々までも行き渡つて招り，年及用途は䍿加し。 眅賣高は加速度的に累加乙て居りま对。日本はての分 野に於ては，原料に惠まれている故に遥していますが， 現在では到底品質，價格の㕫に於て敵し得ないが，大 い令後の研究に期待をして良いて思いすす。改良， 研究が今後代殘された課題ですります。

\section{日本の䕙維工業に街するアメリカの見解に วいて}

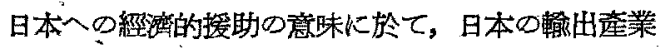
を助長するその基盤は繊維工業であるという理解を持 つている。先般紡績制限を撤廃したのる，との考克方 から出ているものと思います。

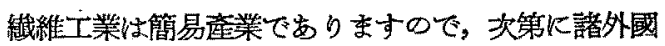
に於て自給消費の態勢をとるために，各民族の自給産 業となりつつある傾问にあります。それ故に長い年月 の希望を持つととが出來ず，重化學工業の方が日本の 最後の工業であるといら意見も一部に性すります。が 然し之を行らには，實際に達成するためには努力が必 罗であり，新工夫がなされなければならない。重化學 工業に重點をおくととは理想的でありまして，現在に 於ては瀻維工業か輸出產業の中心で名ります。而して テメリカ及びイギทスと對抗してやつて行かねばなり ません。生活水淮が上れ傎銀も上つて來ます。

生座設備並に技俭の默で皆樣の絕大なる御努力を括 願い乙，日本瀻維工業の發展を達成して行きたい念願 ですります（本稿は志る10月17日行和れた讙演會に 特ける講演の要旨であり文責は編集會議にあり) 